\title{
Fluorescent Synthetic Receptors for Signaling Hydrogen Sulphide in Living Systems
}

\author{
Kaloo MA ${ }^{1 *}$, Shah $\mathrm{WA}^{2}$, Bhat $\mathrm{BA}^{1,2}$, Gani $\mathrm{M}^{1}$ \\ ${ }^{1}$ Department of Chemistry, Govt. Degree College Shopian, Jammu and Kashmir, India; ${ }^{2}$ Department of Chemistry, University of Kashmir, \\ Hazratbal, Srinagar, Jammu and Kashmir, India
}

\begin{abstract}
In this work, we have compiled literature wherein various attempts regarding design and development of abiotic molecular receptors amid fluorescent signaling response for selective detection of various sulphur species $\left(\mathrm{H}_{2} \mathrm{~S}\right.$, $\mathrm{HS}$, $\mathrm{SO}_{3}^{2-} \mathrm{S}^{2-}$ ) in living cells has been presented. We have specifically compiled the literature which presents the molecular systems deciphering the real-time potential for targeting mentioned chemical species under biological conditions or living cells. With regard to the chemical aspects of designed receptors, focus has been primarily diverted towards interaction of analyte with the receptor molecule at active site. The interaction driven output as a result of electronic modulation in the molecule has been discussed besides detection limit of the analyte. In addition to all this, we have also summarized the conditions for tracking of various Sulphur species in biosystems. The proposed receptors from the literature have been categorized into five classes depending on the mechanism of encounter between analyte and receptor molecule responsible for fluorescence signaling.
\end{abstract}

Keywords: Fluorescence; Receptor; Sulphite; Hydrogen sulfide; Cellular; Imaging

\section{INTRODUCTION}

Sulphur (S) presents one of the important components that find a diverse and wider existence in living systems besides environment. Under the biological conditions, it exists in diverse forms depending on $\mathrm{pH}$. Various forms of sulphur include hydrogen sulphide $\left(\mathrm{H}_{2} \mathrm{~S}\right)$, sulphide ion $\left(\mathrm{S}^{2-}\right)$, sulphite $\left(\mathrm{SO}_{3}{ }^{2}\right)$ and bisulphate (HS). Hydrogen sulfide one of the commonly found member of the reactive sulfur species, traditionally considered as toxic gas with rotten egg smell. It plays crucial role in regulating the intracellular redox and other primary signaling processes involved in human health and disease [1]. It may interact with downstream proteins by the posttranslational cysteine sulfydration and binding to iron centers, which regulate various physiological processes, including ischemia reperfusion injury, vasodilation, apoptosis and angiogenesis [2-4]. A pH-dependent equilibrium mixture with sulfite and bisulfite ions is formed when sulphur dioxide $\left(\mathrm{SO}_{2}\right)$ is dissolved in water. A variety of respiratory diseases cardiovascular diseases and neurological disorders can be induced by frequently exposure of excessive levels of $\mathrm{SO}_{2}$ and its derivatives via environmental waters or through food $[5,6]$.

Hence it is important to have effective monitoring of chemical species like $\mathrm{H}_{2} \mathrm{~S}, \mathrm{~S}^{2}, \mathrm{SO}_{3}{ }^{2-}$ and $\mathrm{HS}$ under aqueous conditions as well as in biosystems. In this regard, development of cost effective and convenient analytical tools is need of an hour. Looking at this important aspect, researchers in recent past have looked at the basis of supramolecular analytical chemistry to produce abiotic molecular species in the form of "Receptors". Among the receptors, molecules deciphering fluorescent singling behavior are the ones which have to some extent shown promise for effective monitoring of mentioned sulphur based chemical species. In this review, we have presented a number of fluorescent probes or reeptors for the sulphur species detection with a show a good selectivity, high sensitivity and suitability for recognition in living cells besides environment. We have categorized these receptors as per the type of chemical reaction that has been induced by the present of anayte during the recognition events.

\section{Receptors based on cleavage reaction}

In this direction, thiolysis of 2,4-dinitrophenyl ether-based receptor 1 (Figure 1) by HS ion is reported by Sayed et al. The 2,4-dinitrophenyl ether moiety of 1 is non-fluorescent in PBSethanol 9:1 v/v mixture. However, presence of $\mathrm{HS}$ induces hydrolysis of 2,4-dinitrophenyl ether moiety which yield the highly fluorescent 8-hydroxy quinoline group [7]. The fluorescent signaling response was fund suitable enough to detection minimum of 60

Correspondence to: Kaloo MA, Department of Chemistry, Govt. Degree College Shopian, 192303-Kmr, India, Tel: 01933260204; E-mail: makandchem@gmail.com

Received: January 04, 2019; Accepted: January 14, 2019; Published: January 21, 2019

Citation: Kaloo MA, Shah WA, Bhat BA, Gani M (2019) Fluorescent Synthetic Receptors for Signaling Hydrogen Sulphide in Living Systems. Biochem Anal Biochem 8:375. doi: 10.35248/2161-1009.19.8.375.

Copyright: (C) 2019 Kaloo MA, et al. This is an open-access article distributed under the terms of the Creative Commons Attribution License, which permits unrestricted use, distribution, and reproduction in any medium, provided the original author and source are credited. 


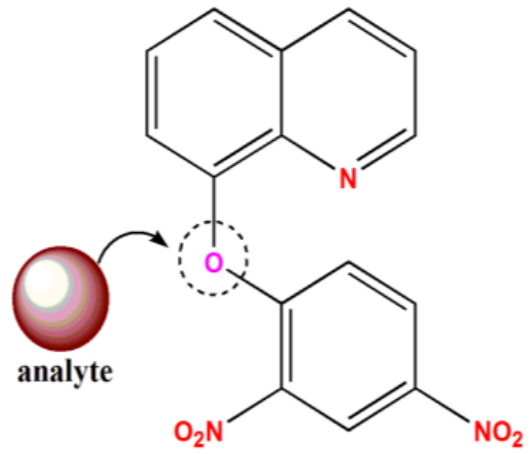

Figure 1: Molecular structure of receptor (1), with active site responsible for the detection of analyte (HS) encircled.

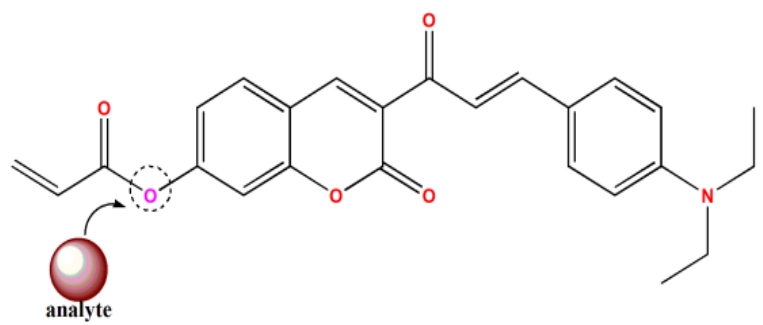

Figure 2: Molecular structure of receptor (2), with active site responsible for the detection of $\mathrm{SO}_{3}^{2-}$ encircled.

nM of analyte. Regarding biological applications, receptor was found to be non-toxic to HeLa cells in the range concentrations of 5-50 $\mu \mathrm{M}$. In this experiment, HeLa cells were incubated in DMEM and supplemented with $10 \%$ fetal bovine serum. The cells were seeded in $24 \mathrm{~mm}$ glass cover slips in 6-well plates and allowed to settle for 24 hours. Then the cells were treated with 1 in DMSO (1\%) at $30 \mathrm{mM}$. After 20 minutes, medium was removed and solutions of different concentrations of NaHS in PBS were incubated for another 10-minute period. The cells incubated with 1 showed no fluorescence, whereas a marked enhancement in intracellular emission was observed in the HS treated cells with 1, clearly indicating the possible use of 1 to detect hydrogen sulphide.

In another report, coumarin based receptor molecule 2 (Figure 2) was reported by Xie. Author reported that the reaction mechanism for detection of $\mathrm{SO}_{3}{ }^{2-}$ involves a nucleophilic addition reaction on the proposed molecule, followed by intramolecular cyclization, and finally cleavage. Such an interaction between analyte and receptor finally ends up with fluorescence signaling response. The detection limit of 2 for $\mathrm{SO}_{3}{ }^{2 \cdot}$ was found to be $0.52 \mu \mathrm{M}$. Concerning living cell applications, receptor was found to be non-toxic to B16 cells in the range concentrations of $0-10 \mu \mathrm{M}$. In this direction, author studied that its capability to detect sulphite anion in living cells. He observed that once B16 cells were incubated with the receptor molecule 2 for $20 \mathrm{~min}$, an obvious fluorescence was found in green and blue channels. However, when the probe 2 was treated with the $\mathrm{SO}_{3}{ }^{2-}$ ion, the fluorescence was increases in green cells dramatically. Hence, the detection of $\mathrm{SO}_{3}{ }^{2-}$ via green channel in living cells is doable.

\section{Receptors based on nucleopilic addition reaction}

In this direction, a coumarin-hemicyanine receptor 3 (Figures 3 and 4) was studied by Wang et al. The molecular receptor interacts with sulphite anion via nucleophilic addition followed by rearrangement-based reaction mechanism, and such a molecular transformation in turn triggers fluorescence "turn on" response. The receptor was found suitable to detect analyte around at a

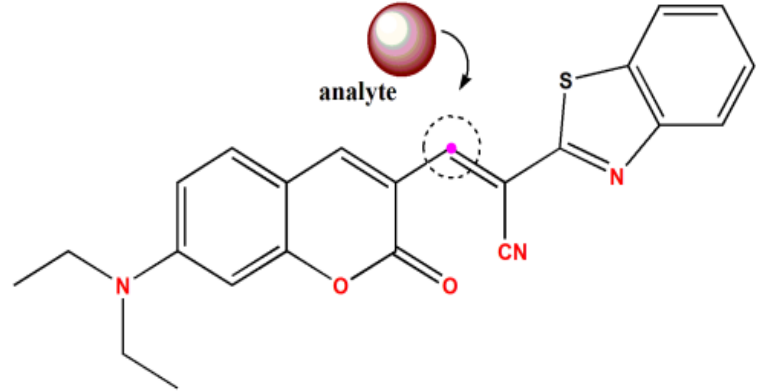

Figure 3: Molecular structure of receptor (3), with active site responsible for the detection of $\mathrm{SO}_{3}{ }^{2}$ encircled.

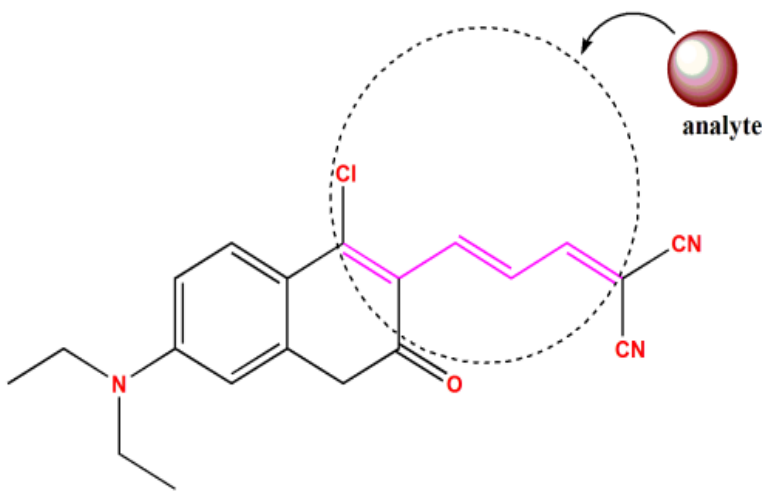

Figure 4: Molecular structure of receptor (4), with active site responsible for the detection of $\mathrm{H}_{2} \mathrm{~S}$ encircled.

minimum of $0.08 \mu \mathrm{M}$. Importantly it had a low cytotoxicity after a long period of 24 hours. For further living cell applications, author carried out an MTT assay with different concentrations of $\mathrm{SO}_{3}{ }^{2}$. anion via a fluorescence imaging experiment in living cells. For bio-imaging applications, freshly grown HeLa cells were incubated with $\mathrm{SO}_{3}{ }^{2-}(100 \mu \mathrm{M})$ for $30 \mathrm{~min}$ and were washed with PBS two times. Cells were subsequently treated with probe $3(5.0 \mu \mathrm{M})$ for around 30 mins. The probe 3 was found to be cell-permeable and showed a bright fluorescence due to the reaction with intracellular $\mathrm{SO}_{3}{ }^{2-}$ anion which was later found in good agreement with the fluorescence turn-on profile of the receptor in the presence of $\mathrm{SO}_{3}{ }^{2-}$ in vitro.

In another study, F. Chen reported a potent fluorescent receptor for sensitive and selective detection of $\mathrm{H}_{2} \mathrm{~S}$ in different buffer solutions. The key design principle is based on a coumarin moiety which acts as a fluorophore. The receptor design is structuring three potential active sites that could react with $\mathrm{H}_{2} \mathrm{~S}$. A strong fluorescent in red and green channels were observed as a result of nucleophilic attack on active sites of the proposed receptor. The detection limit of 4 for hydrogen sulphide was found to be $75 \mathrm{nM}$. It was found permeable to cells and possess low cytotoxicity. The live cell applications of receptor were reported with bioimaging study investigated in MCF-7 cells.

\section{Receptors based on reduction reaction}

In a study reported by Guo et al. two non-fluorescent receptors containing nitro $\left(-\mathrm{NO}_{2}\right)$ group in 5 and azide $\left(-\mathrm{N}_{3}\right)$ group in 6 (Figure 5) were studied for anion recognition during various fluorescence experiments. The fluorescent signaling response was attributed to the generation of amine functionality on the molecule by the reduction of nitro or azide group. The readout response was found suitable to detect analyte at a minimum of $5-10 \mu \mathrm{M}$ and 1-5 
$\mu \mathrm{M}$ respectively for each receptor. In the bioimaging experiments, human cervical carcinoma cell lines (HeLa cells) were incubated with 5 and 6 (30 min). The HeLa cells images were non-fluorescent at low $\mathrm{H}_{2} \mathrm{~S}$ concentration after the incubation. However, the cells became fluorescent (turn on) after $250 \mu \mathrm{M} \mathrm{H}_{2} \mathrm{~S}$ when the cells were incubated for another $30 \mathrm{~min}$. This indicates that 5 and 6 are concentration dependent for the detection of $\mathrm{H}_{2} \mathrm{~S}$ in the living cells.

\section{Receptors based on complexation reaction}

This strategy is one of the oldest utilized molecular receptor approaches for detection of analyte during diverse analytical monitoring. In this direction, Meng et al. reported fluoresceinaldazine based fluorescent receptor (Figure 6) for $\mathrm{S}^{2}$ ions in aqueous solution [8]. It displays a reversible fluorescent respose with "ON-OFF-ON" mechanism in living cells. In this case, $\mathrm{Cu}^{2+}$ ion coplex of the receptor is created and then used to detection the $\mathrm{S}^{2-}$ via decomplexation mechansm. The detection limit of this receptor 7 was found to be $0.15 \mu \mathrm{M}$. For studying the potential applications of this receptor in living systems, cells were incubated with a $5 \mu \mathrm{M}$ solution of receptor 7 for $30 \mathrm{~min}$ at $37^{\circ} \mathrm{C}$. Then the cells were washed three times with PBS. After incubating the cells

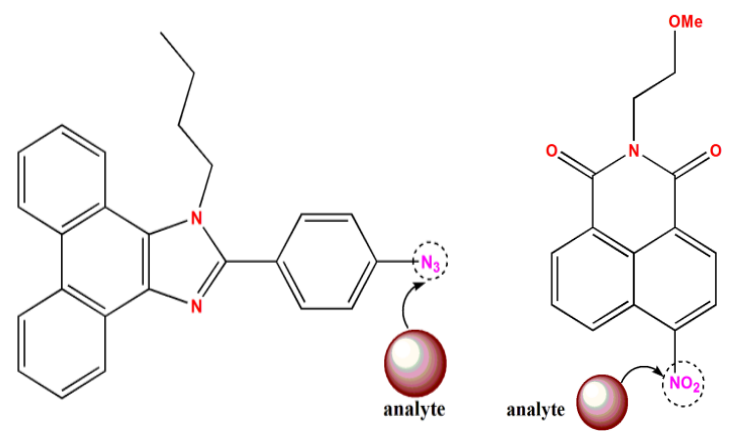

Figure 5: Molecular structure of receptor 6 (left) and 5 (right), with active sites for the detection of $\mathrm{H}_{2} \mathrm{~S}$ encircled.

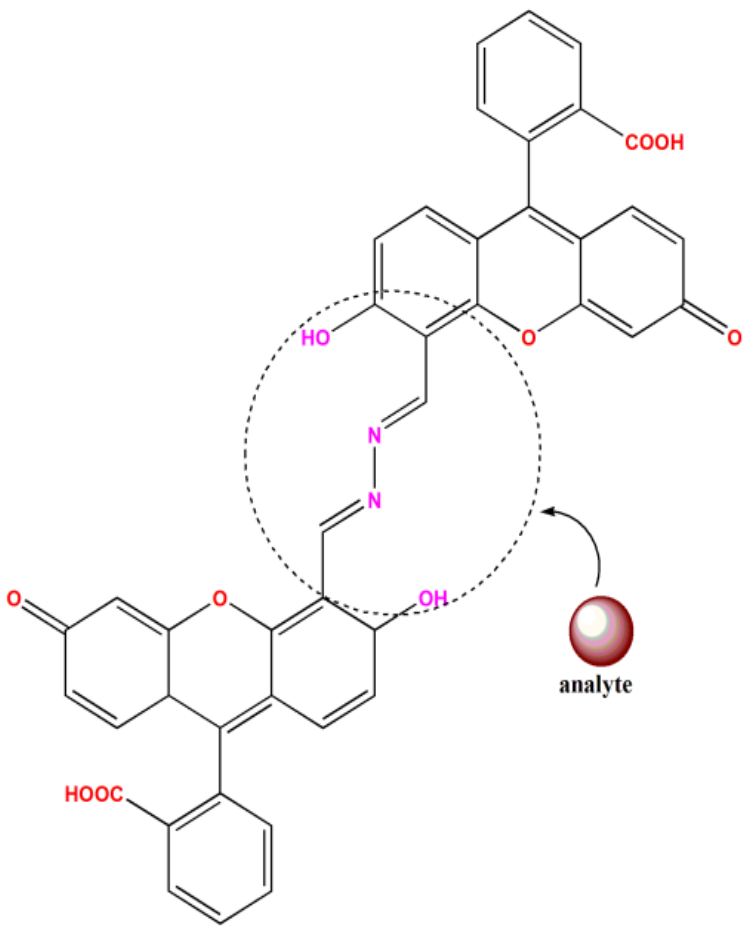

Figure 6: Molecular structure of receptor (7), with active site responsible for the detection of $S^{2}$ encircled. with sodium sulfide $(10 \mu \mathrm{M})$ for another $10 \mathrm{~min}$, an intense green fluorescence was observed, hence deciphering potential cellular applications.

In another similar type of study, $\mathrm{C} \mathrm{Li}$ reported a reversible fluorescent probe 8 (Figure 7) for sequential recognition of $\mathrm{Cu}^{2+}$ and $\mathrm{S}^{2}$ in aqueous and biological media. Author reported a reversible fluorescent sensing response in the form of "ON-OFFON" of fluorescence from the receptor molecule. The detection limit of receptor 8 was found to be $0.11 \mu \mathrm{M}$. He studied that the HeLa cells displayed the strong green fluorescence after incubated with the probe for 30 minutes at $37^{\circ} \mathrm{C}$. After the addition of 10 $\mathrm{mM} \mathrm{Cu}{ }^{2+}$ for $10 \mathrm{~min}$ at $37^{\circ} \mathrm{C}$, the strong fluorescence was vanished, indicating complex compound of probe 8 with cation. However, after treating with $20 \mathrm{mM} \mathrm{S}^{2}$ for 10 min under same temperature conditions, strong fluorescence was recovered back, indicating that the probe has a high sensitivity and selectivity for $\mathrm{S}^{2}$ on the bases of forming CuS.

\section{Receptors based on deprotonation reaction}

This is one of the recent studies which has taken the anion-induced deprotonation mechanism into account for the detection of $\mathrm{S}^{2}$. In this direction, Kumar et al. reported Pyridine-2,6-dicarboxamide based molecular receptors for the selective detection of $\mathrm{S}^{2-}$ ions [9]. However, here we have mentioned best among the receptors reported in his work which possess benzothiazole rings 9 (Figure 8). This receptor which is selective for the $\mathrm{S}^{2-}$ ion in aqueous as well as living cells contrary to the other one. The detection limit of 9 for the analyte was calculaed to be $1.28 \mu \mathrm{M}$. During the biological study, after the incubation of L929 cells, receptor was treated with anion and a strong fluorescence (green channel) was observed. The cell imaging studies clearly illustrate that the developed receptor molecule has good cellular permeability, and shows effective interaction with sulfide ion inside the cells.

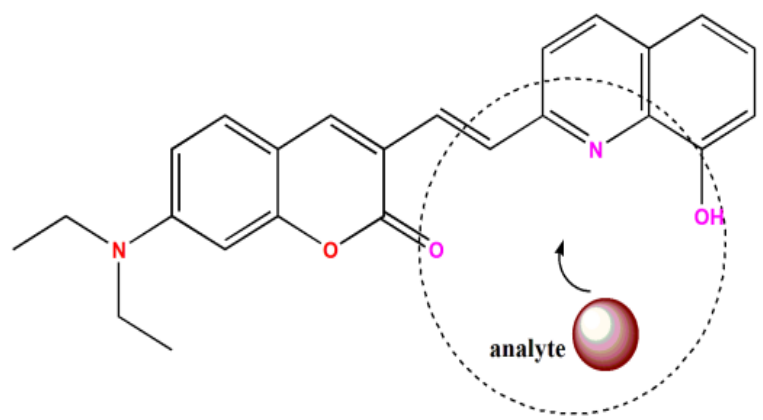

Figure 7: Molecular structure of receptor (8), with active site responsible for the detection of $\mathrm{S}^{2-}$ encircled.

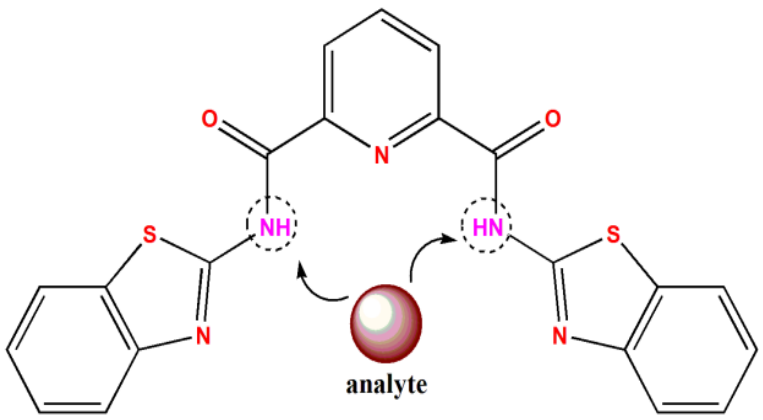

Figure 8: Molecular structure of receptor (9), with active site responsible for the detection of $\mathrm{S}^{2-}$ encircled. 


\section{CONCLUSIONS}

In this work, we present a review of literature about single molecular receptor approach for the recognition of various species of sulphur like $\mathrm{H}_{2} \mathrm{~S}$, HS and $\mathrm{SO}_{3}{ }^{2-}$ under living cell environment. The receptors which have been selected herein are robust under ambient conditions as well as inside living matrices. We have solely focused on molecules deciphering recognition signal as fluorescence which is strong enough to track the target sulphur species in minimal amounts in living cells. The categorization of designed and proposed receptor strategies has been presented with respect to the mechanistic aspects involved during the course of anion interaction with proposed molecules. The encounter between receptor molecules and sulphur species has been recognized with either reversible (Chemosensing) or irreversible (Chemodosimetry) pathway. In addition to the molecular structure of the mentioned receptors, sensitivity of receptors, detection limit has also been highlighted.

Even though, much has been talked about selectivity of proposed receptors for these anionic sulphur species, but specific recognition of any of these is still to be looked at. In this direction, exclusive selectivity for $\mathrm{HS}$ and $\mathrm{SO}_{3}{ }^{2}$ inside intracellular matrix will be highly desirable as these are the crucial sulphur based anions involved inside the cells. Besides these, other aspects like toxicity of the new formed receptor species particular fragments produced as a result of Chemodosmetry triggered by anion needs to be taken into account while developed novel receptors. We believe the state of art target molecules discussed in this work will keep researchers (biologists, biochemists, analytical chemists, etc.) interested in the arena at the top of the field while looking to develop futuristic molecular designs which is highly efficient and convenient for complete apportionment of sulphur inside living systems.

\section{ACKNOWLEDGEMENTS}

We highly acknowledge Head of Institute (Dr. Ali Mohammad Dar) and department of chemistry, Govt Degree College Shopian for their support throughout the work. M. A. Kaloo gratefully acknowledges Department of Science and Technology, New Delhi for INSPIREFACULTY research grants [DST/ INSPIRE/04/2016/000098].

\section{REFERENCES}

1. Lippert AR, New EJ, Chang CJ. Reaction-based fluorescent probes for selective imaging of hydrogen sulfide in living cells. J Am Chem Soc. 2011;133:10078-10080.

2. Blackstone $\mathrm{E}$, Morrison $\mathrm{M}$, Roth $\mathrm{MB} . \mathrm{H}_{2} \mathrm{~S}$ induces a suspended animation-like state in mice. Sci. 2005;308:518.

3. Yang G, Wu L, Jiang B, Yang B, Qi J, Cao K, et al. $\mathrm{H}_{2} \mathrm{~S}$ as a physiologic vasorelaxant: hypertension in mice with deletion of cystathionine gamma-lyase. Sci. 2008;322:587.

4. Yang G, Wu L, Wang R. Pro-apoptotic effect of endogenous $\mathrm{H}_{2} \mathrm{~S}$ on human aorta smooth muscle cells. FASEB J. 2006;20:553-555.

5. Iwasawa S, Kikuchi Y, Nishiwaki Y, Nakano M, Michikawa T, Tsuboi T, et al. Effects of $\mathrm{SO}_{2}$ on respiratory system of adult Miyakejima resident 2 years after returning to the island. J Occup Health. 2009;51:38-47.

6. Sang N, Yun Y, Li H, Hou L, Han M, Li G. SO Inhalation Contributes to the Development and Progression of Ischemic Stroke in the Brain. Toxicol Sci. 2010;114:226-236.

7. Guo Z, Chen G, Zeng G, Li ZW. Fluorescent and colorimetric sensors for environmental mercury detection. Analyst. 2015;140:5400-5443.

8. Meng Q, Zhang R, Jia H, Gao X, Wang C, Shi Y, et al. A reversible fluorescence chemosensor for sequentially quantitative monitoring copper and sulfide in living cells. Talanta. 2015;143:294-301.

9. Kumar P, Gupta R, Kumar V, Pandey S. Detection of sulfide ion and gaseous $\mathrm{H}_{2} \mathrm{~S}$ using a series of pyridine-2,6-dicarboxamide based scaffolds. Dalton Trans. 2018;47:9536-9545. 